\title{
Using ALOS PALSAR derived high-resolution DInSAR to detect slow-moving landslides in tropical forest: Cameron Highlands, Malaysia
}

\section{Mustafa Neamah Jebur, Biswajeet Pradhan \& Mahyat Shafapour Tehrany}

To cite this article: Mustafa Neamah Jebur, Biswajeet Pradhan \& Mahyat Shafapour Tehrany (2015) Using ALOS PALSAR derived high-resolution DInSAR to detect slow-moving landslides in tropical forest: Cameron Highlands, Malaysia, Geomatics, Natural Hazards and Risk, 6:8, 741-759, DOI: $10.1080 / 19475705.2013 .860407$

To link to this article: http://dx.doi.org/10.1080/19475705.2013.860407

(.) 2013 Taylor \& Francis

Citing articles: 12 View citing articles $4 \pi$ $\sqrt{6}$ Submit your article to this journal $\square$

View related articles $\sqsubset$ à
Published online: 02 Dec 2013. 


\title{
Using ALOS PALSAR derived high-resolution DInSAR to detect slow-moving landslides in tropical forest: Cameron Highlands, Malaysia
}

\author{
MUSTAFA NEAMAH JEBUR, BISWAJEET PRADHAN (10 * and \\ MAHYAT SHAFAPOUR TEHRANY \\ Department of Civil Engineering, Facul of Engineering, University Putra Malaysia, \\ 43400 UPM, Serdang, Selangor, Malaysia
}

(Received 14 July 2013; accepted 24 October 2013)

\begin{abstract}
Landslide is one of the natural hazards that pose maximum threat for human lives and property in mountainous regions. Mitigation and prediction of this phenomenon can be done through the detection of landslide-susceptible areas. Therefore, an appropriate landslide analysis is needed in order to map and consequently understand the characteristic of this disaster. One of the recent popular remote sensing techniques in deformation analysis is the differential interferometric synthetic aperture radar which is popularly known as DInSAR. Due to the mass vegetation condition in Malaysia, a long-wavelength synthetic aperture radar $(\sim 24 \mathrm{~cm})$ is required in order to be able to penetrate through the forests and reach the bare land. For that reason, ALOS PALSAR HH imagery was used in this study to derive a deformation map of the Gunung Pass area located in the tropical forest of the Cameron Highlands, Malaysia. In this study, the ascending orbit ALOS PALSAR images were acquired in September 2008, January 2009 and December 2009. Subsequently the displacement measurements of the study site (Gunung Pass) were calculated. The accuracy of the result was evaluated through its comparison with ground truth data using the $\mathrm{R}^{2}$ and root mean square error (RMSE) methods. The resulted deformation map showed the landslide locations in the study area from interpretation of the results with $0.84 \mathrm{R}^{2}$ and $0.151 \mathrm{RMSE}$. The DInSAR precision was $11.8 \mathrm{~cm}$ which proved the efficiency of the proposed method in detecting landslides in a tropical country like Malaysia. It is highly recommended to use the proposed method for any other deformation studies.
\end{abstract}

\section{Introduction}

Synthetic aperture radar (SAR) systems have been widely used in the past two decades to produce high-resolution mapping and other remote sensing applications (Calabro et al. 2010; Sun et al. 2011). The ability of penetrating the cloud and dayand-night operation made the SAR systems unique compared to optical imagery and in situ measurements. Also, it is known to be unaffected by sun-illumination and atmospheric conditions (Karjalainen et al. 2012). SAR data are increasingly applied to geophysical problems, either by themselves or in conjunction with data from other remote sensing instruments (Biro et al. 2013; Pradhan et al. 2013). Examples of such applications include polar ice research (Gourmelen et al. 2011; Hassaballa et al.

\footnotetext{
*Corresponding author. Email: biswajeet24@gmail.com or biswajeet@upm.edu.my
} 
2013), land use mapping (Mahmoud et al. 2011; Chen et al. 2013), vegetation and biomass measurements (Lardeux et al. 2011) and natural hazards (e.g. Pradhan et al. 2010b; Billa \& Pradhan 2011; Herrera et al. 2013).

In recent years, radars have given a new dimension to the disaster management research by providing real-time and precise information (Pradhan et al. 2009; Elbialy et al. 2013). Deformation of the ground surface can occur through man-made or naturally induced factors. Geological phenomena such as earthquakes, subsidence, volcanic activity, glacial rebound and landslides are the main contributors of ground deformation (Pradhan \& Lee 2010). Human causes of displacements include mining activities and excessive groundwater (e.g. water, gas, oil) exploitation, etc. So it is critical to have a clear understanding about the impacts of each activity in order to have proper and sustainable management over the area. Landslide is one of the major natural disasters that cause frequent damage in a steep terrain (Dahal et al. 2012). Thus, mapping, monitoring and analyzing the susceptible areas for these disasters help the governments and agencies to protect lives and property (Pourghasemi et al. 2013).

DInSAR is a robust method to detect positional changes on the Earth's surface caused by landslides or other natural disasters (Abidin et al. 2012; Jebur et al. 2013; Idrees et al. 2013a). DInSAR can be generated by calculating the difference between two interferograms belonging to three data sets acquired at different times. If any small positional changes occur during this period of data collection, it can be precisely detected through this technique (Cascini et al. 2010). These surface displacements can be measured through the space by near to centimetre accuracy using the SAR imagery, covering a vast area. Terrain elevation changes are the main source of information in many areas of research. The DInSAR technique utilizes the phase difference between pairs of the SAR image acquired from the same area at different times, which is generally recorded by same observation parameters. At least two interferograms are needed to be generated, i.e. before and after the event, which induced the landform variation (Catani et al. 2005). From the computed interferograms, the DInSAR technique allows the estimation of the projection of the displacements along the radar line of sight (LoS).

The principle of DInSAR was first described by Gabriel et al. (1989). For geological applications, DInSAR technology was used to examine the deformation made by earthquakes (Massonnet et al. 1993). Over the years, many studies have been carried out using DInSAR technology on various applications such as tectonic events (Colesanti et al. 2003), volcanic deformation (Lagios et al. 2005), landslides (e.g. Farina et al. 2006; Meisina et al. 2008; Guzzetti et al. 2009; Lauknes et al. 2010; Yin et al. 2010), ground motions due to fluid exploitation (Sarychikhina et al. 2010), geothermal related activities (Manzo et al. 2012), subsidence episodes (Trasatti et al. 2008) and mining subsidence (Castañeda et al. 2009).

The results presented in the aforementioned papers are an evidence of the usefulness of DInSAR in various applications including landslide studies. Since the traditional landslide monitoring methods are time consuming and costly, DInSAR plays a key role in land displacement monitoring. Yin et al. (2010) used integration of GPS and DInSAR observations to monitor the Jiaju landslide along the deep-cut valley in the western Sichuan. In a recent paper, Guzzetti et al. (2009) performed multitemporal DInSAR to extract the deformations and their impact, which happened in the Umbria region from 1992 to 2000 . The number and percentage of the landslides and land subsidence were investigated for that area. 
In a recently published paper, Idrees et al. (2013b) reviewed some of the popular DInSAR algorithms to monitor the deformations of the ground and stated that all the methods were able to detect the displacements by different spatial resolutions. De Agostini et al. (2012) added DInSAR outputs into their prediction analysis to produce a map consisting of spatial and temporal information on landslides that occurred in 2010. Ardizzone et al. (2012) stated that landslide analysis cannot be an efficient using single method, while it needs integration of data and information at different temporal and spatial scales. They proposed DInSAR as a standard and precise technique to detect and map the landslide events.

Herrera et al. (2013) applied DInSAR using the integration of multi-SAR data of ALOS PALSAR images (2006-2010), ERS, Envisat (2001-2007) and TerraSAR-X (2008) data sets. Their results indicated that using multi-SAR data analysis, the complex landslide dynamics will be understood better and thus improved analysis may be carried out. In another paper, $38 \%$ of the landslides in the Tena valley could be detected and their results were examined using differential GPS (D-GPS) (Herrera et al. 2013). The same group of authors tried to compare the performance of DInSAR using the single-data type of ALOS PALSAR with the output of multiband DInSAR from a previous study of the same study area (García-Davalillo et al. 2013). Results of the comparison analysis indicated that DInSAR made by one data type could detect deformation with larger spatial coverage than multiband DInSAR. However, it could recognize lower number of landslides compared to multiband DInSAR (9 against 51). The best performance was achieved using a combination of these two methods, which could map and monitor $68 \%$ of the landslides in Tena Valley (García-Davalillo et al. 2013). Roering et al. (2009) utilized a combination of DInSAR and LiDAR and archived air photos to detect the large, slow-moving landslides in the Eel River catchment, northern California. They could identify five large ( $>1 \mathrm{~km}$ long) landslides that occurred between 2007 and 2008. Their results reflected the potential use of ALOS interferometry and airborne LiDAR to track small landslides.

The highest penetration of SAR signals through the vegetation cover can be obtained using the L band of the ALOS PALSAR satellite by its $24 \mathrm{~cm}$ wavelength signal (e.g. Strozzi et al. 2005; Herrera et al. 2013). More recently, with the advent of a high-resolution SAR sensor such as Terra-SAR-X, it is possible to use a more accurate source of data in DInSAR imagery (Liao et al. 2012). Unfortunately, due to its relatively high cost of data acquisition, it was not used in the current research. Also other platforms such as ERS 1/2 (Guzzetti et al. 2009), JERS (Alimuddin et al. 2013), Radarsat (Pepe et al. 2011) and Envisat (Pepe et al. 2005) are available, but in most of the deformation studies ALOS PALSAR is recommended for use (Honda et al. 2012; García-Davalillo et al. 2013). Furuta et al. (2005) gathered information about the capabilities of ALOS PALSAR in interferometry studies. They found that ALOS PALSAR is very useful for producing accurate digital elevation models (DEMs) and deformation monitoring, as well as disaster monitoring and hazard prevention.

The Cameron Highlands in Malaysia has faced many landslides which caused considerable damage to waterways, property, livestock and pipelines (Pradhan \& Lee 2010). The Gunung Pass area, which is located in the Cameron Highlands, is highly prone to landslides due to heavy rainfall and weak soil structure. Recently the area has suffered heavy damage from landslides and requires fast and accurate deformation analysis for implementing preventive measures (Pradhan \& Lee 2010). 
Previously, some landslide susceptibility analysis had been done by some researchers in this area (Pradhan \& Lee 2010; Pradhan et al. 2010a; Pradhan et al. 2010b; Rauste et al. 2012), but there was not any attempt to use deformation analysis through the DInSAR method. For instance, Pradhan and Lee (2010) used an artificial neural network to generate a landslide susceptibility map of the Cameron Highlands with $83 \%$ accuracy. The aim of this study is to map the landslides which happened in May 2009 using the DInSAR technique to illustrate the efficiency of the proposed method.

\section{Study area and data used}

The used scenes cover Barisan Titiwangsa Mountains in Malaysia. Banjaran or Barisan Titiwangsa is the longer of the two mountain ranges that run through West Malaysia stretching from Thailand down to Negeri Sembilan. It reaches its highest altitude of 7138 feet at the peak of Ginning Korbu near the mining town of Ipoh. The study was conducted between the Perak and Pahang states in the Gunung Pass area of the Cameron Highlands district, as shown in figure 1. Gunung Pass is a tropical rainforest which is geographically located at a latitude of $04^{\circ} 35^{\prime} 55^{\prime \prime} \mathrm{N}$ and longitude $101^{\circ} 20^{\prime} 49^{\prime}$ E. The elevation of the road is $1391 \mathrm{~m}$ above mean sea level, while the peak of Gunung Pass reaches $1540 \mathrm{~m}$ above mean sea level. The lithology of the Cameron Highlands mainly consists of Quaternary and Devonian granite and schist (Pradhan et al. 2008; Pradhan et al. 2010b). The rocks of the Gunung Pass area consist of a sequence of metasedimentary rocks, which are confined within a 4-km-wide, $\mathrm{N}$ to NNE trending belt (Malone et al. 2008). It has been reported by a previous study (Khan 2010) that landslides took place in the Gunung Pass area on the Simpang Pulai-Cameron Highlands highway in 2009.

Selection of SAR images is a very critical task, as the data should possess some specific characteristics in order to be used in interferometric processing. It is a key

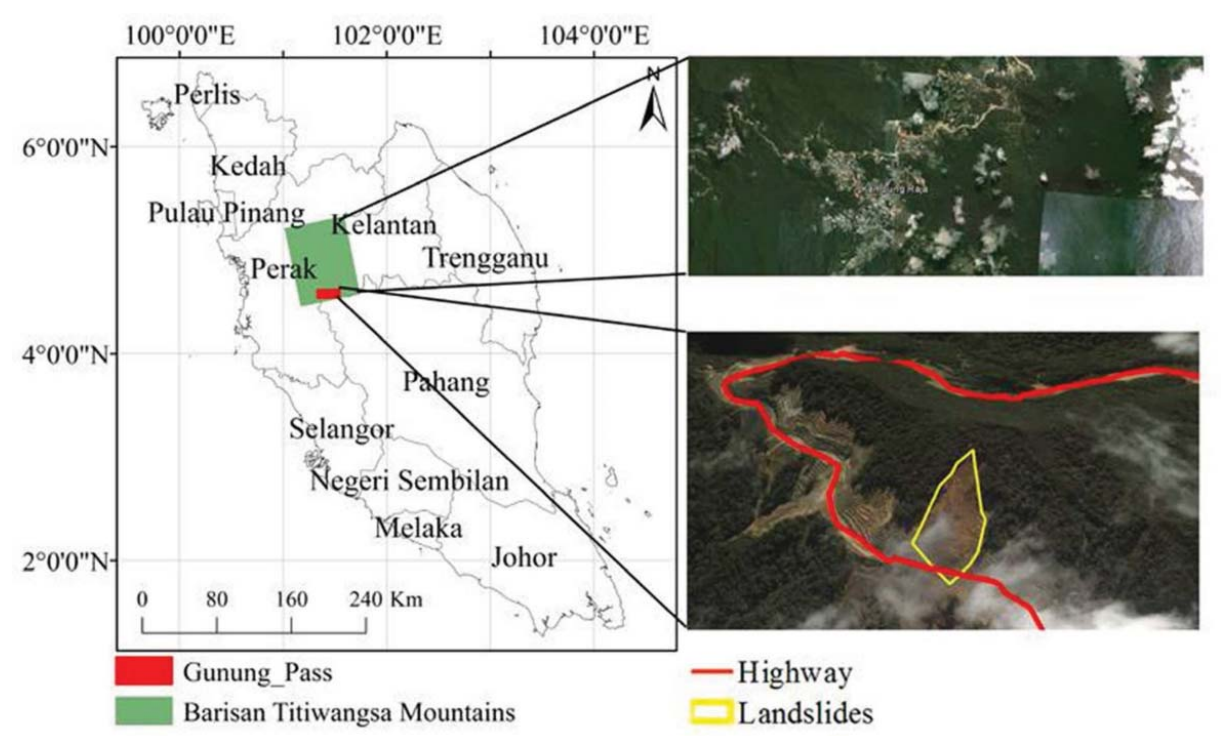

Figure 1. Study area location map (yellow ellipse showing the location of the landslide). 
step, since the criteria adopted for selection of images have a strong impact on the quality of the final results. These criteria depend on the specific application for which the SAR interferometric images are acquired. For that reason, a pair of $\mathrm{HH}$ polarized L bands of ALOS PALSAR data were used for the purpose of interferometric generation. The data were acquired in September 2008 and January and December 2009. The range sampling frequency, chirp bandwidth and bit quantization are $32 \mathrm{MHz}, 28 \mathrm{MHz}$ and 5 bits, respectively.

\section{Methodology}

In the following sections, the main characteristics of the InSAR and DInSAR procedures are described using the PalsarProcessor and PalSarFringe programs.

\subsection{Ground survey}

First, the location of the landslides was detected using a GeoExplorer 6000 handheld GPS. Using the differential method, the accuracy of the collected points was down to centimetre level - either post-processed or in real-time methods. Furthermore, the collected data were used for refinement of the resulted interferogram. Other information such as horizontal movement of the landslide was obtained from in situ measurements conducted by Jamaludinl et al. (2008). Data were acquired on 12 December 2007 using an automatic robotic total station (Sokkia SRX) which is stationed near the Gunung Pass landslide. The restriction of the LoS to the existing survey locations led to the use of two stations at the southern end and northern end of the slope. In order to protect the stations from varied weathering conditions, they were mounted on a concrete structure. Some of the location points which were very close to each other or were not located in proper places were removed before using them in the processing. In this study, only 20 location points were used and the analysis was done using these points (table 1). The data were transferred from sites to the Main Control Center located at the Public Works (PWD, Malaysia) Headquarters in Kuala Lumpur using GSM communication. Subsequently, the shifted distance was measured and used in the validation of this study.

\subsection{Preprocessing}

ALOS PALSAR data were acquired as level 1.0 which represents the signal information, and the data to be processed further changed to one level higher, containing phase and magnitude information, i.e. 1.1 (Shimada 1998). To process SAR interferometry, the original SAR signal must be processed to single look complex (SLC) data which is called SAR image reconstruction (Schmitt \& Stilla 2010). The PALSAR processor is a tool that was used to convert the PALSAR level 1.0 data into SLC data.

\subsection{SAR orthorectification}

High-precision information of the corrected image is required for removing the geometric distortions (Ren \& Chang 2012). For each pixel, equations (1) and (2) must be fulfilled. Using these equations, the relationship between the single 
Table 1. Survey location points and their displacements.

\begin{tabular}{lcc}
\hline Station number & Horizontal displacement & Vertical displacement \\
\hline 1 & 1.185 & 0.321 \\
2 & 1.245 & 0.678 \\
3 & 2.587 & 0.257 \\
4 & 4.587 & 3.245 \\
5 & 2.459 & 3.265 \\
6 & 5.296 & 4.218 \\
7 & 8.489 & 7.265 \\
8 & 9.847 & 8.201 \\
9 & 3.583 & 2.035 \\
10 & 4.597 & 4.132 \\
11 & 6.524 & 5.289 \\
12 & 6.589 & 4.235 \\
13 & 7.298 & 5.289 \\
14 & 5.279 & 2.954 \\
15 & 6.215 & 3.854 \\
16 & 9.169 & 7.689 \\
17 & 5.952 & 4.982 \\
18 & 3.124 & 2.145 \\
20 & 2.218 & 1.658 \\
\hline
\end{tabular}

backscatter element, sensor and their related velocities is calculated and therefore the illumination geometry and the processors' characteristics are extracted. This complete reconstruction of the imaging and processing geometry took into consideration the topographic effects (foreshortening, layover) as well as the influence of the Earth rotation and terrain height on the Doppler frequency shift and azimuth geometry. In this study, an ASTER DEM was used for this purpose with $30 \mathrm{~m}$ spatial resolution.

$$
\begin{gathered}
R=S-P, \\
f_{D}=\frac{2 f_{0}\left(v_{b}-v_{s}\right) R_{s}}{c\left|R_{S}\right|},
\end{gathered}
$$

where $R_{s}, S$ and $P$ are the slant range, spacecraft and backscatter element position, respectively. Similarly, $v_{b}$ and $v_{s}$ are the spacecraft and backscatter element velocity, respectively; $f_{0}, c$ and $f_{D}$ are the carrier frequency, speed of light and processed Doppler frequency, respectively.

\subsection{SAR interferogram generation}

After processing the two images, a pair of SLC data were extracted which were utilized in the SAR interferogram generation. For that reason, an InSAR pair consisting of two scenes referred to as a master image and a slave image was used to construct the interferogram (Ren \& Chang 2012). One of the scenes was used as a master image, and the other data were used to overlay on that as a slave image. In order to increase the phase of the fringe with respect to the height, the slave orbit 


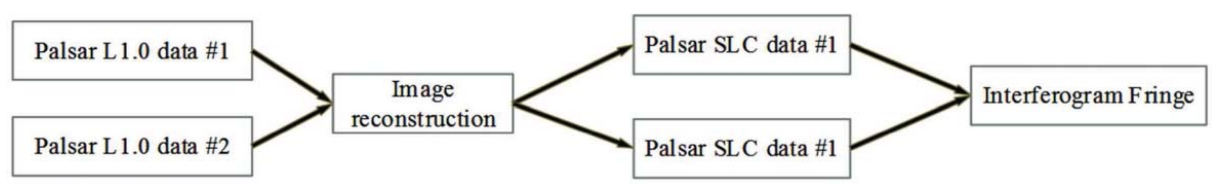

Figure 2. The preprocessing steps for fringe generation.

position must be at the right side of the master orbit position ( $\mathrm{Yu} \& \mathrm{Ge} 2010)$. The difference between $r 1$ and $r 2(\Delta r)$ can be measured by the phase difference $(f)$ between two complex SAR images using equation (3) (Sousa et al. 2011). This is performed by multiplying one image by the complex conjugate of the other one, which resulted in the formation of the interferogram. The phase of the interferogram contains fringes that trace the topography like contour lines. These images should have a suitable baseline, according to the image selection criteria (Navarro-Sanchez et al. 2010). The baseline between the master and slave images for the first and second interferograms was $279 \mathrm{~m}$ and $292 \mathrm{~m}$, respectively. The general steps of interferogram generation are shown in figure 2 .

$$
\varnothing=\frac{4 \pi}{\lambda}(\Delta R)
$$

where $\Delta R$ is the slant range difference from satellite to target at different times and $\lambda$ is the ALOS PALSAR wavelength which is about $23.62 \mathrm{~cm}$.

\subsection{SAR interferogram post-processing}

Due to the noisy nature of the resulted interferogram, a proper filter should be used in order to remove the bias of the output. There are some common filters mentioned in the literature such as the Goldstein filter (Goldstein \& Werner 1997), sigma filter (Lee et al. 2009) and simple average (Colavita et al. 2010); however, based on trial and error, the best noise reduction was achieved using the Goldstein filter. The Goldstein filter is an adaptive radar interferogram filter which is based on the concept of multiplication of the Fourier spectrum $Z(u, v)$ of a small interferogram patch by its smoothed absolute value $S\{|Z(u, v)|\}$ to the power of an exponent $\propto$ (Lu et al. 2010). The filter was applied with the weight value of 0.5 as it is not recommended to have a high value of weight (Wang et al. 2011). The generated interferogram was orthorectified using an ASTER DEM.

\subsection{Phase unwrapping}

The range of the phase module is represented in $2 \pi$. So, the time that changes in phase reaches to $2 \pi$ the cycle will be repeated (Navarro-Sanchez et al. 2010). In order to resolve the $2 \pi$ ambiguity, phase unwrapping was applied. There are some popular methods to serve the purpose, such as region growing (Ojha et al. 2012), minimum cost flow (Pepe \& Lanari 2006), branch-cuts (Estrada et al. 2012), minimum least squares (Navarro-Sanchez et al. 2010), multibaseline (Xianming \& Yiming 2011), etc. In the current research, the region growing method was used and for its 
parameters level 1 decomposition and 0.15 thresholds were selected. It is recommended to use a low coherence threshold $(0.15-0.2)$ in order to have enough freedom during the analysis (Ojha et al. 2012).

\subsection{SAR differential interferogram}

The temporal separation in repeat-pass interferometry of days, months or even years can be used for long-term monitoring of geodynamic phenomena such as glacial or lava-flow movements (Sumantyo et al. 2012). However, it is also useful to analyze the results of single events, such as earthquakes. As such, the observed phase $\left(\varnothing_{\text {int }}\right)$ is the sum of several contributions. The objective of DInSAR is to extract information from the different components so that the displacement $\left(\varnothing_{\text {Movement }}\right)$ can be calculated using equation (4); the displacement sensitivity of DInSAR is given in equation (5).

$$
\varnothing_{\text {int }}=4 \pi \frac{R_{1}-R_{2}}{\lambda}=\varnothing_{\text {Topography }}+\varnothing_{\text {Change }}+\varnothing_{\text {movement }}+\varnothing_{\text {Atmosphere }}+\varnothing_{\text {Noise }} \cdots
$$

$$
\frac{\partial \varnothing_{d}}{\partial \xi}=\frac{4 \pi}{\lambda}
$$

where $\partial \xi$ is the deformation. A differential interferogram can be generated in different ways, as shown in figure 3 . In the first case, passes 1 (pre-event) and 2 (afterevent) in combination with a DEM (used for subtracting the topography induced fringes) were considered (Marghany 2012). In the second case, in order to avoid the DEM generation and isolate movements associated with the event, passes 1 and 2 were combined with passes 1 and 3 ).

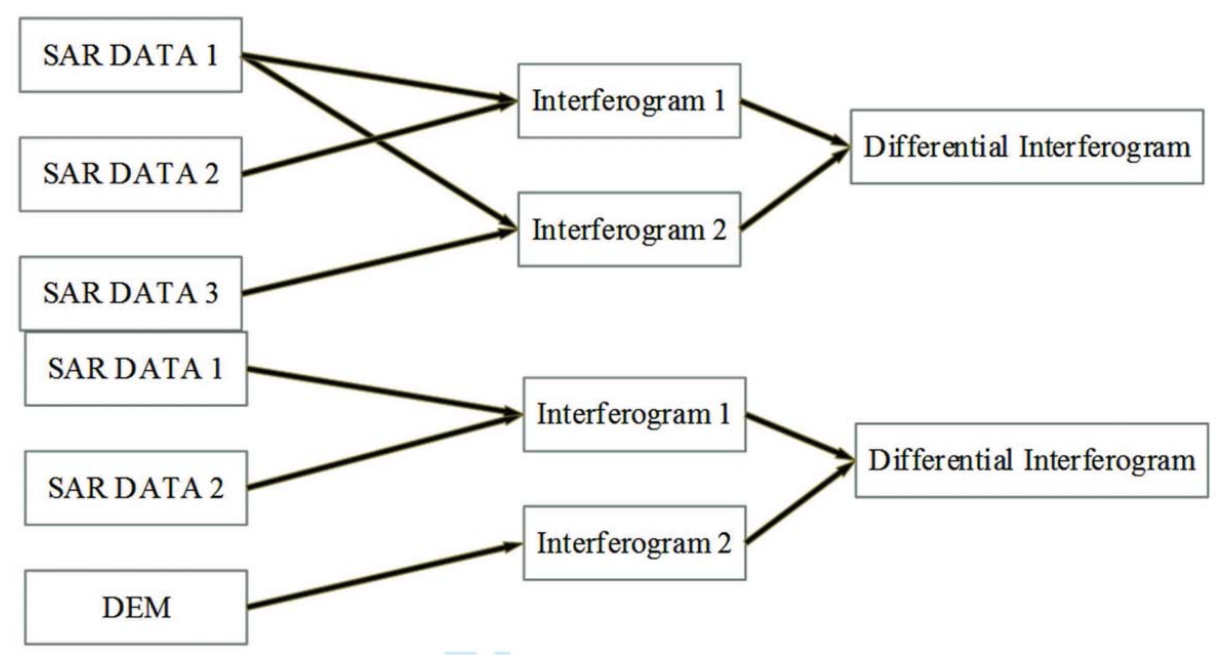

Figure 3. The general steps of differential interferogram generation used in this study. 


\subsection{Validation}

The efficiency and quality of the developed interferogram should be examined using a proper method. The results can be validated using the statistical method of $\mathrm{R}^{2}$ and RMSE (Askne et al. 2003). The validation has been done by comparing in situ measurements (table 1) with the displacement results using equations (6) and (7).

$$
\mathrm{RMSE}=\sqrt{\frac{1}{N}-\sum_{i=1}^{N}\left(M_{i}-O_{i}\right)^{2}}
$$

where $N$ is the number of verifying points, $M_{i}$ are the points measured using the resulted interferogram and $O_{i}$ are the points collected by in situ measurement.

$$
R^{2}=1-\frac{S S_{\text {res }}}{S S_{\text {tot }}}
$$

where $S S_{\text {res }}$ is the residual sum of the squares and $S S_{\text {tot }}$ is the total sum of the squares.

\section{Results and discussion}

After applying the full SLC processing, three pairs of scenes could be achieved which were used later in the processing of the fringe generation. The SLC data were orthorectified in order to represent the reality in terms of the geographic location, as shown in figures 4 and 5. As mentioned earlier, one master and two slaves were used to generate the two interferogram fringes.

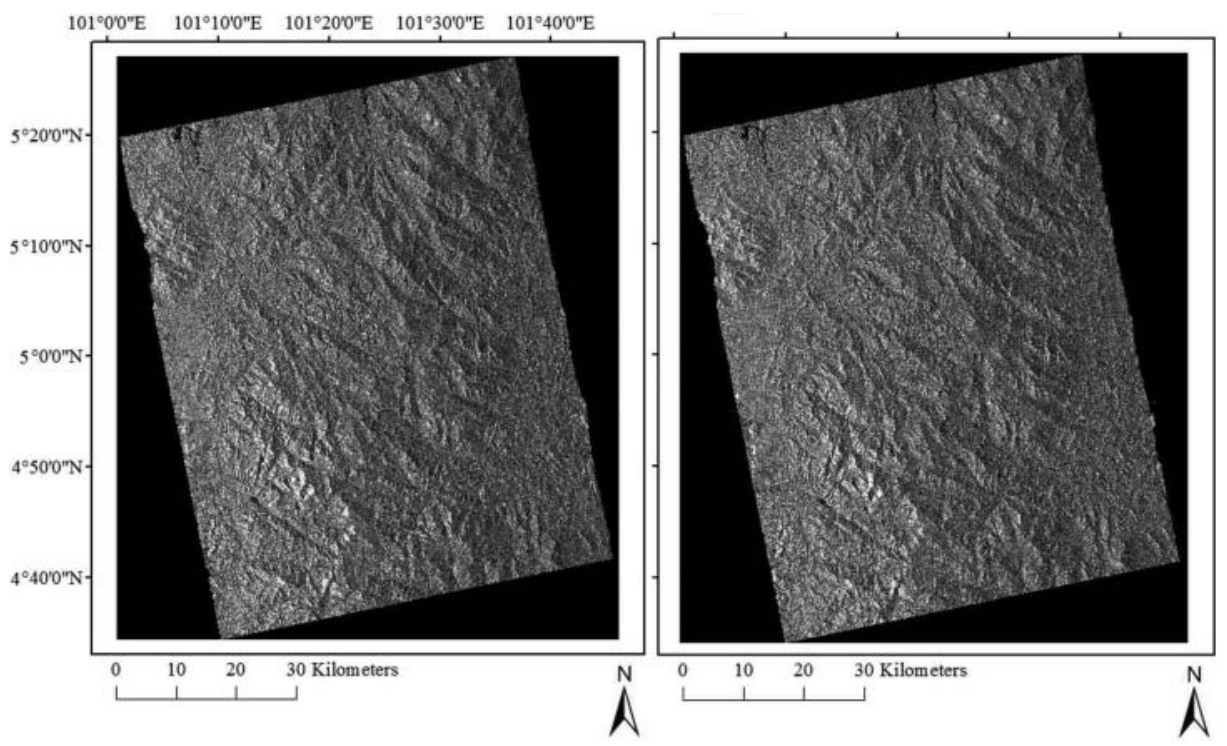

Figure 4. The master (left) and slave (right) images of the first interferogram. 


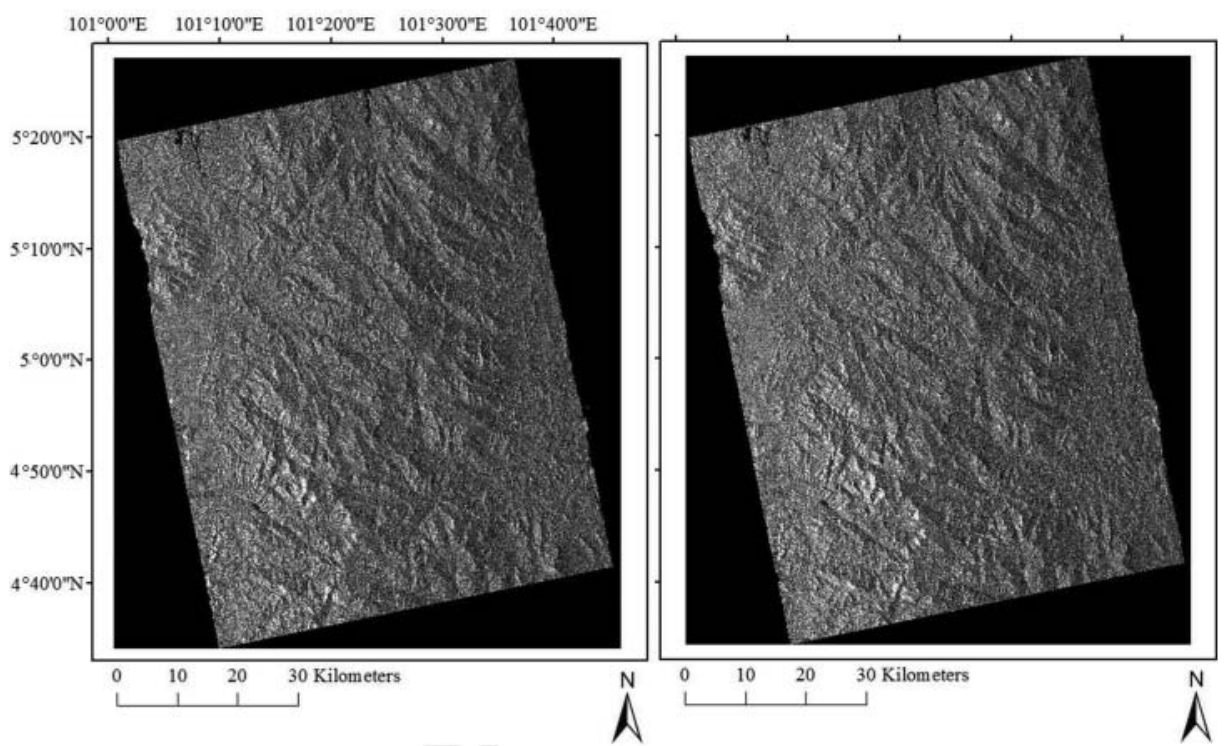

Figure 5. The master (left) and slave (right) images of the second interferogram.

After that, the two fringes were generated using two pair data where the result was represented in a greyscale interferogram. Subsequently, the fringes were divided into many subareas surrounded by phase jump edges as the subarea borders. In a subarea, the phase advanced in accordance with increase of brightness. In contrast, an increment of phase jump occurred at the border, as shown in figure 6(a). The resulted fringe had a lot of noise which has been clarified in Section 3.4. After applying the Goldstein filter, the result had a better appearance, as shown in figure $6(b)$. Then, region growing was used and for its parameters level 1 decomposition and a 0.15 threshold were selected for phase unwrapping. For that purpose, interferograms were orthorectified using an ASTER DEM, as shown in figure 7. The resulted interferogram ranged between $218.5 \mathrm{~m}$ and $-218.5 \mathrm{~m}$ and could measure the difference in height for the chosen data.
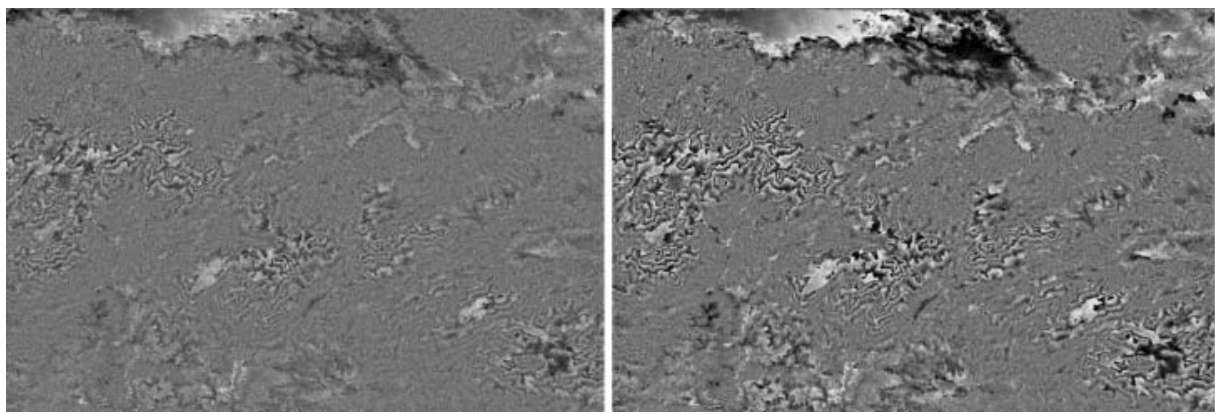

Figure 6. The fringe of the first interferogram (left) and the fringe after applying the Goldstein filter with a weight of 0.7 (right). 


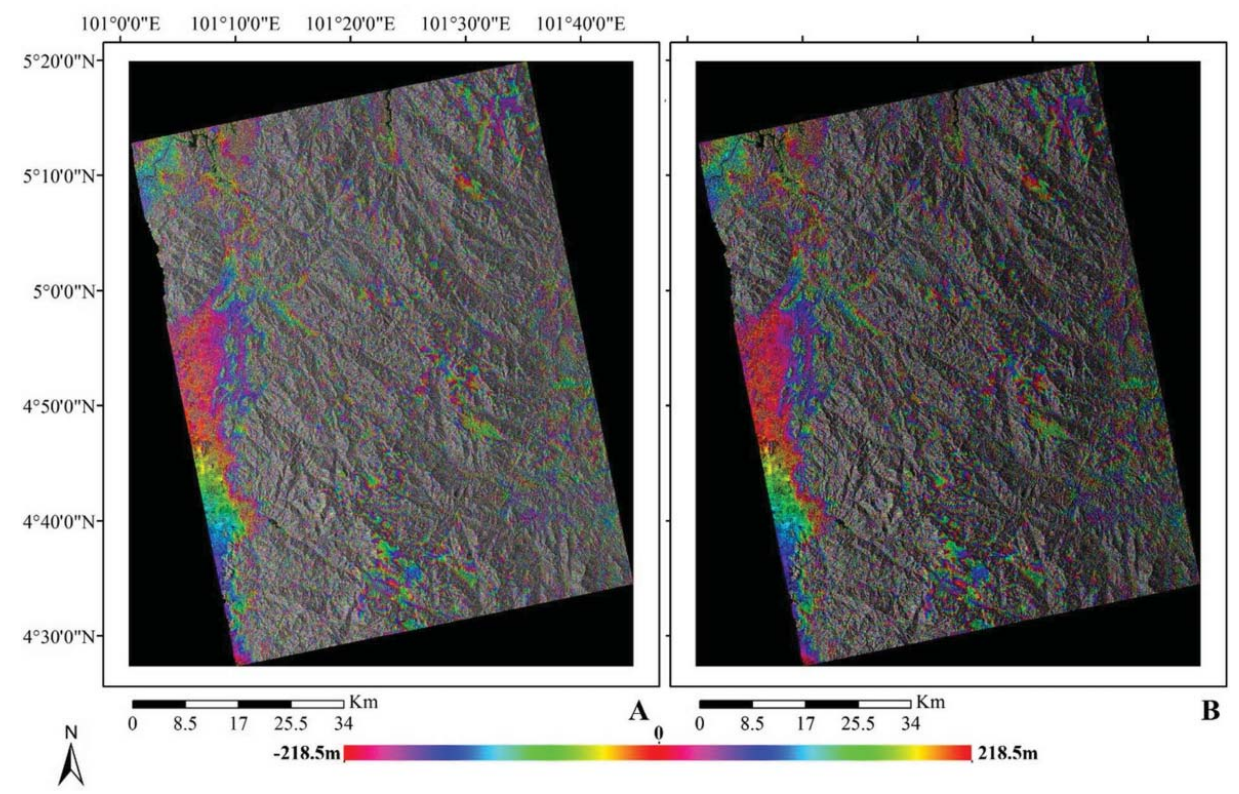

Figure 7. The results of the orthorectified interferogram (January (left) and December (right) 2009).

Subsequently, both interferograms were combined together for the purpose of differential interferogram generation, as shown in figure 8 . The results showed that the differential interferogram had a displacement of 11.8 per cycle $(\pi)$.

The main objective of this paper was to detect the areas that had been deformed by landslides; however, a large number of areas had been ignored because of vegetation coverage, depending on the SAR signal that can penetrate through the vegetation to different depths. Therefore, differential interferometry is not applicable for vegetation analysis. The final result of DInSAR is shown in figure 9 which clearly represents the landslide movement across the highway of Gunung Pass. Also, figure 10 shows the non-landslide areas in order to facilitate differentiating landslide and nonlandslide areas. It can be seen that no interference happened in the fringes.

Landslides were detected and mapped for further studies. The area of the landslides was calculated using GIS tools which showed the amount of movement around $54,000 \mathrm{~m}^{2}$. The area was calculated by subtracting the regions showing high distortion. Then, it was transferred to ArcGIS for area calculation based on the deformation scale. The black arrow in figure 9 shows the direction of the movement of the landslides. Landslides were quantitatively represented using 60 points that were chosen to prepare the profile of displacement as a function of elevation (figure 11). The range of the horizontal movement of displacements varied between 1 and $10 \mathrm{~m}$.

For the purpose of validation, the RMSE and $\mathrm{R}^{2}$ methods were used (Papoutsis et al. 2013; Shirzaei et al., 2013). The horizontal measurement data, mentioned in table 1, were used to validate the detected landslides. For that purpose, 20 points were used and both $\mathrm{R}^{2}$ and RMSE were calculated and a regression relation was plotted, as shown in figure 12 . The resulted $\mathrm{R}^{2}$ was 0.841 with RMSE 0.115 which were quite reasonable for the current study. 


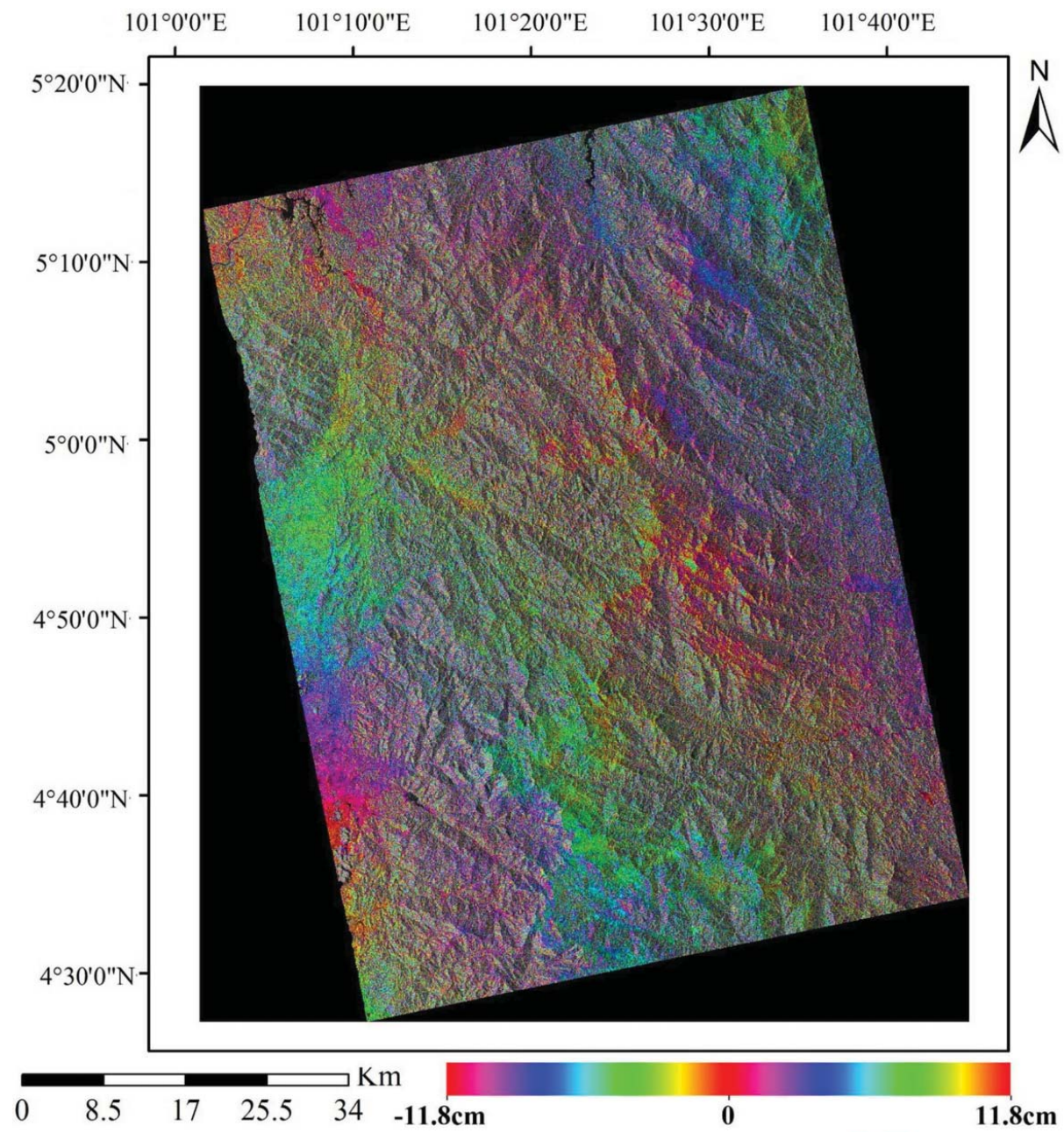

Figure 8. The result of the differential interferogram (December 2009).

\section{Conclusion}

Natural hazards such as landslides have serious and devastating consequences: huge loss of lives and property. So, it is wise to detect the mass movement caused by landslides through proper scientific and cost-effective methods in order to analyze their characteristics. Many methods have been developed to recognize and detect these movements; however, most of them have some weak points which reduce the reliability and efficiency of these methods. Also, landslides can happen in remote areas where field work is not feasible. As in hazard studies time is paramount for the emergency response, DInSAR is the best choice for identifying large areas that have been moved in a very short time. This study has demonstrated the detection of horizontal movement of landslides using DInSAR generated by the ALOS PALSAR L band. Selection of proper imagery has a significant impact on the final output of the interferometric processing. Landslides mainly happen in areas covered by vegetation and 


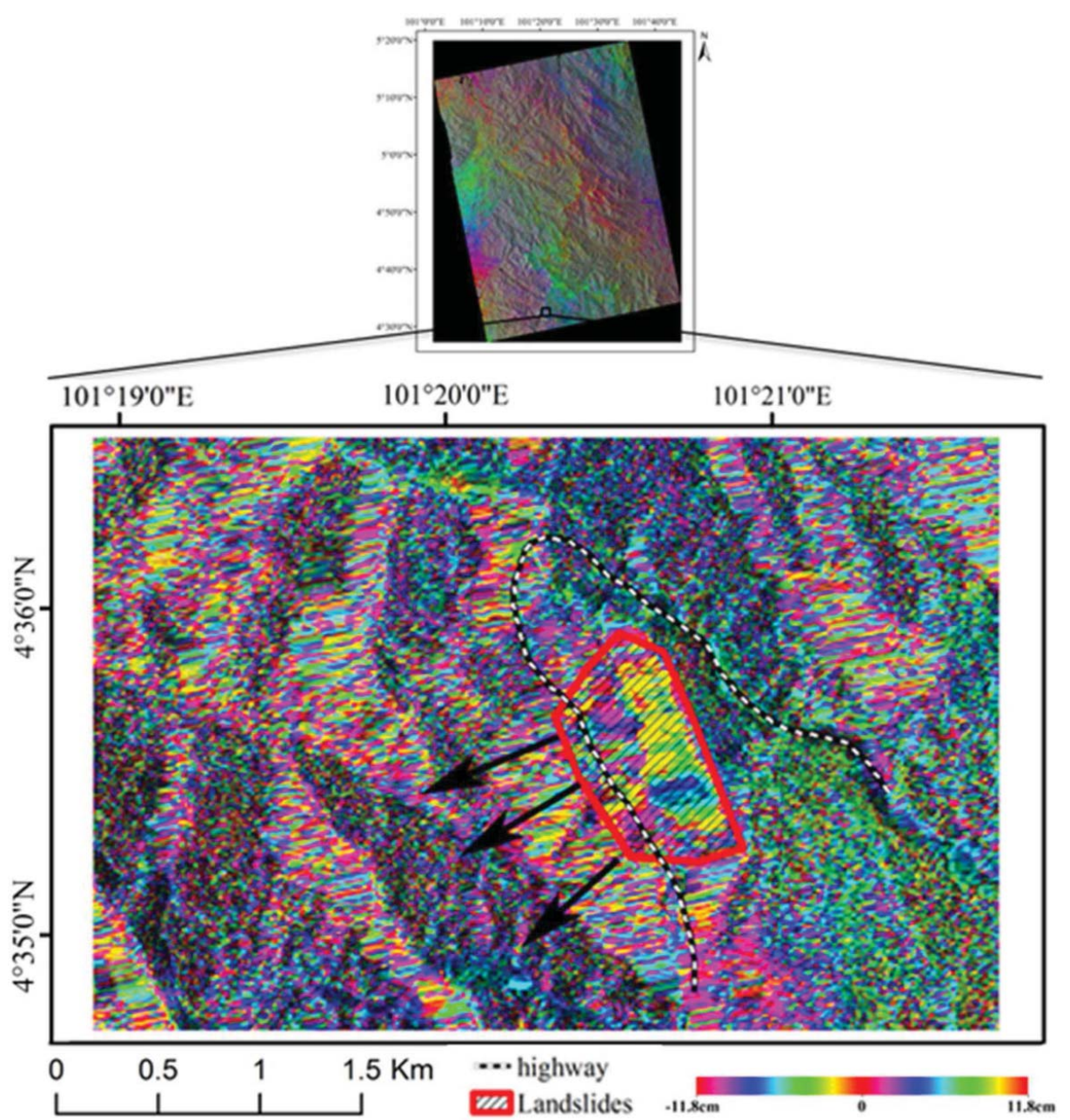

Figure 9. The area of deformation with the metric unit.
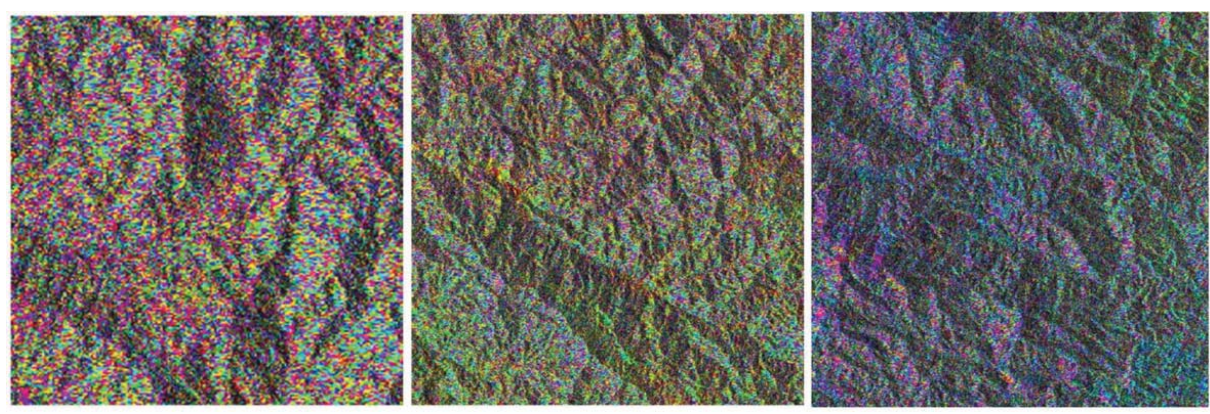

Figure 10. Area representing a non-landslide region. 


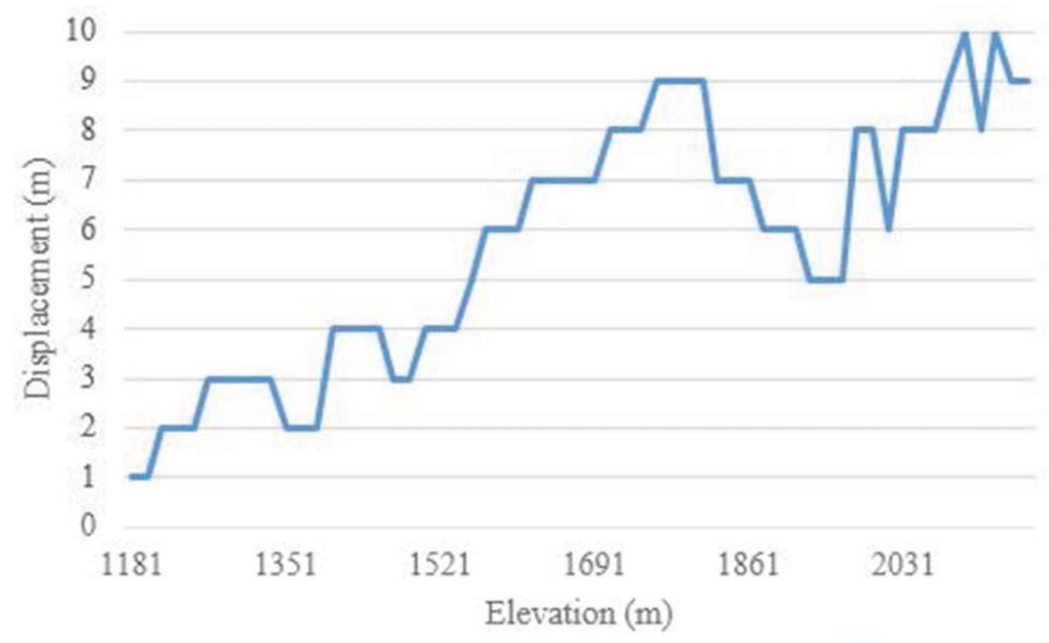

Figure 11. Profile of displacement.

have a cloud cover. The ALOS PALSAR is an L-band frequency $(1.27 \mathrm{GHz})$ radar capable of continental scale interferometric observations. The highest penetration of SAR signals through the vegetation cover can be obtained using the $\mathrm{L}$ band of the ALOS PALSAR satellite, through its $24 \mathrm{~cm}$ wavelength signal, which enables continuous recording from the ground of the whole area.

The result exhibited an accurate fringe pattern which showed deformation with $11.8 \mathrm{~cm}$ accuracy with $0.84 \mathrm{R}^{2}$ and $0.151 \mathrm{RMSE}$. Using GIS tools the area of the landslides was calculated which showed approximately $54,000 \mathrm{~m}^{2}$ movement. The location of the landslide was detected clearly and precisely which proved that DInSAR is a powerful tool, which can be used to detect any positional changes in the vertical horizontal movement of the Earth surface. The method proposed in this

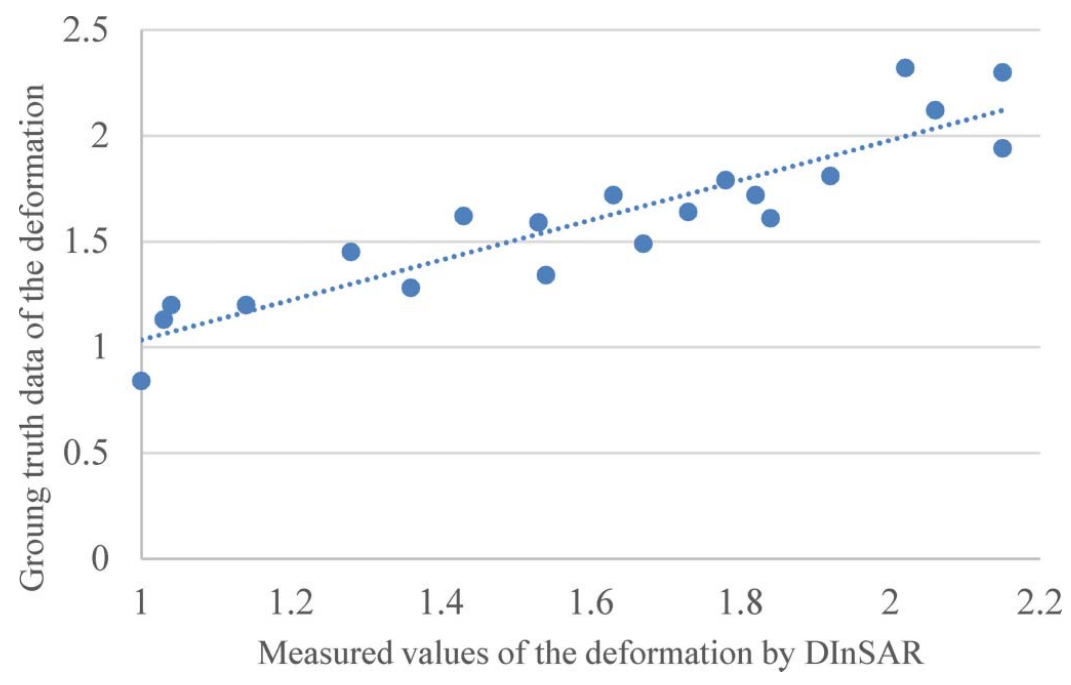

Figure 12. The scatter plot of the testing point's validation. 
research can be used for planning and assessment purposes. Landslide maps can be used as an efficient indicator for managers and planners in order to select a proper location for transportation and other infrastructure. The results achieved in this study can be used as basic data to apply more comprehensive analysis such as landslide volume measurement, damage assessment and prevention. Also, more pair of data can be used in order to analyze a series of DInSAR in future studies.

\section{Acknowledgements}

The authors would like to thank two anonymous reviewers for their critical reviews on an earlier version of the manuscript. Also, the authors are grateful to the Public Works Department, Malaysia, and, in particular, Mr Suhaimizi for providing the literature on the Gunung Pass landslide.

\section{ORCID}

Biswajeet Pradhan (10) http://orcid.org/0000-0001-9863-2054

\section{References}

Abidin HZ, Andreas H, Gumilar I, Sidiq TP, Fukuda Y. 2012. Land subsidence in coastal city of Semarang (Indonesia): characteristics, impacts and causes. Geomatics Nat Hazard Risk. 4:1-15. doi:10.1080/19475705.2012.692336.

Alimuddin I, Bayuaji L, Maddi HC, Sri Sumantyo JT, Kuze H. 2013. Developing tropical landslide susceptibility map using DInSAR technique of JERS-1 SAR data. Int J Remote Sensing Earth Sci. 8:32-40.

Ardizzone F, Angeli MG, Calò F, Castaldo R, Federica F, Guzzetti F, Lollino P, Manconi A, Manunta M, Manzo M. 2012. Temporal and spatial analysis of landslides through the SBAS-DInSAR approach: the Ivancich, Assisi, test case. Paper presented at: the EGU General Assembly Conference Abstracts; Vienna, Austria.

Askne J, Santoro M, Smith G, Fransson JE. 2003. Multitemporal repeat-pass SAR interferometry of boreal forests. IEEE Trans Geosci Remote Sensing. 41:1540-1550.

Billa L, Pradhan B. 2011. Semi-automated procedures for shoreline extraction using single Radarsat-1 SAR image. Estuarine Coastal Shelf Sci. 95:395-400.

Biro K, Pradhan B, Suleiman H, Buchroithner MF. 2013. Evaluation of TerraSAR-X data for land use/land cover analysis using object-oriented classification approach in the African Sahel area, Sudan. J Indian Soc Remot Sens. 41:539-553. doi.org/10.1007/s12524012-0230-7.

Calabro MD, Schmidt DA, Roering JJ. 2010. An examination of seasonal deformation at the Portuguese bend landslide, Southern California, using radar interferometry. J Geophys Res:Earth Surf. 115:1-10. doi:10.1029/2009JF001314.

Cascini L, Fornaro G, Peduto D. 2010. Advanced low-and full-resolution DInSAR map generation for slow-moving landslide analysis at different scales. Eng Geol. 112:29-42.

Castañeda C, Gutiérrez F, Manunta M, Galve JP. 2009. DInSAR measurements of ground deformation by sinkholes, mining subsidence, and landslides, Ebro River, Spain. Earth Surf Processes Landforms. 34:1562-1574.

Catani F, Farina P, Moretti S, Nico G, Strozzi T. 2005. On the application of SAR interferometry to geomorphological studies: estimation of landform attributes and mass movements. Geomorphology. 66:119-131.

Chen Z, Zhang Y, Guindon B, Esch T, Roth A, Shang J. 2013. Urban land use mapping using high resolution SAR data based on density analysis and contextual information. Can J Remote Sensing. 38:738-749. 
Colavita MM, Booth AJ, Garcia-Gathright JI, Vasisht G, Johnson Jr RL, Summers KR. 2010. Fringe measurement and control for the Keck interferometer. Publ Astron Soc Pac. 122:795-807.

Colesanti C, Ferretti A, Prati C, Rocca F. 2003. Monitoring landslides and tectonic motions with the permanent scatterers technique. Eng Geol. 68:3-14.

Dahal RK, Hasegawa S, Bhandary NP, Poudel PP, Nonomura A, Yatabe R. 2012. A replication of landslide hazard mapping at catchment scale. Geomatics Nat Hazards Risk. 3:161-192.

De Agostini A, Floris M, Pasquali P, Barbieri M, Cantone A, Riccardi P, Stevan G, Genevois R. 2012. The contribute of DInSAR techniques to landslide hazard evaluation in mountain and hilly regions: a case study from Agno valley (North-Eastern Italian Alps). Paper presented at: the EGU General Assembly Conference Abstracts; Vienna, Austria.

Elbialy S, Mahmoud A, Pradhan B, Buchroithner M. 2013. Application of spaceborne SAR data for extraction of soil moisture and its use in hydrological modelling at Gottleuba Catchment, Saxony, Germany. J Flood Risk Manage. (Article online first available). doi.org/10.1111/jfr3.12037.

Estrada JC, Servin M, Vargas J. 2012. 2D simultaneous phase unwrapping and filtering: a review and comparison. Opt Lasers Eng. 50:1026-1029.

Farina P, Colombo D, Fumagalli A, Marks F, Moretti S. 2006. Permanent scatterers for landslide investigations: outcomes from the ESA-SLAM project. Eng Geol. 88:200-217.

Furuta R, Shimada M, Tadono T, Watanabe M. 2005. Interferometric capabilities of ALOS PALSAR and its utilization. Paper presented at: the Fringe 2005 Workshop; Frascati, Italy.

Gabriel AK, Goldstein RM, Zebker HA. 1989. Mapping small elevation changes over large areas: differential radar interferometry. J Geophys Res. 94:9183-9191.

García-Davalillo JC, Herrera G, Notti D, Strozzi T, Álvarez-Fernández I. 2013. DInSAR analysis of ALOS PALSAR images for the assessment of very slow landslides: the Tena valley case study. Landslides. doi:10.1007/s10346-012-0379-8.

Goldstein R, Werner C. 1997. Radar ice motion interferometry. Paper presented at: the 3rd ERS ESA Symposium Proceedings; Florence, Italy.

Gourmelen N, Kim SW, Shepherd A, Park JW, Sundal AV, Björnsson H, Palsson F. 2011. Ice velocity determined using conventional and multiple-aperture InSAR. Earth Planetary Sci Lett. 307:156-160.

Guzzetti F, Manunta M, Ardizzone F, Pepe A, Cardinali M, Zeni G, Reichenbach P, Lanari R. 2009. Analysis of ground deformation detected using the SBAS-DInSAR technique in Umbria, Central Italy. Pure Appl Geophys. 166:1425-1459.

Hassaballa AA, Althuwaynee OF, Pradhan B. 2013. Extraction of soil moisture from RADARSAT-1 and its role in the formation of the 6 December 2008 landslide at Bukit Antarabangsa, Kuala Lumpur. Arab J Geosci. (Article online first available). doi.org/ 10.1007/s12517-013-0990-6.

Herrera G, Gutiérrez F, García-Davalillo JC, Guerrero J, Notti D, Galve JP, FernándezMerodo JA, Cooksley G. 2013. Multi-sensor advanced DInSAR monitoring of very slow landslides: the Tena valley case study (Central Spanish Pyrenees). Remote Sensing Environ. 128:31-43.

Honda K, Nakanishi T, Haraguchi M, Mushiake N, Iwasaki T, Satoh H, Kobori T, Yamaguchi Y. 2012. Application of exterior deformation monitoring of dams by DInSAR analysis using ALOS PALSAR. Paper presented at: the IEEE International Geoscience and Remote Sensing Symposium (IGARSS); Munich, Germany.

Idrees MO, Saeidi V, Yusuf YA, Pradhan B. 2013a. Advanced differential interferometry SAR techniques for deformation monitoring: A review on sensors and recent research development. Geocarto Int. (Article online first available). doi.org/10.1080/10106049. 2013.807305. 
Idrees MO, Saeidi V, Yusuf YA, Pradhan B. 2013b. Forthcoming. Advanced differential interferometry SAR techniques for deformation monitoring: a review on sensors and recent research development. Geocarto Int. doi:10.1080/10106049.2013.807305.

Jamaludinl S, Jaafar KB, Abdullah CH, Mohamed A. 2008. Landslide warning system for Mount Pass, Malaysia based on surface monitoring technique. Paper presented at: the International Conference on Management of Landslide Hazard in the Asia-Pacific Region; Japan.

Jebur MN, Pradhan B, Tehrany MS. 2013. Detection of vertical slope movement in highly vegetated tropical area of Gunung pass landslide, Malaysia, using L-band InSAR technique. Geosci J. (Article on-line first available). doi.org/10.1007/s12303-013-0053-8.

Karjalainen M, Kankare V, Vastaranta M, Holopainen M, Hyyppä J. 2012. Prediction of plot-level forest variables using Terrasar-X Stereo SAR data. Remote Sensing Environ. 117:338-347.

Khan YA. 2010. Monitoring of hill-slope movement due to rainfall at Gunung Pass of Cameron Highland district of Peninsular Malaysia. Int J Earth Sci Eng. 03:06-12.

Lagios E, Sakkas V, Parcharidis IS, Dietrich V. 2005. Ground deformation of Nisyros Volcano (Greece) for the period 1995-2002: results from DInSAR and DGPS observations. Bull Volcanol. 68:201-214.

Lardeux C, Frison PL, Tison C, Souyris JC, Stoll B, Fruneau B, Rudant JP. 2011. Classification of tropical vegetation using multifrequency partial SAR polarimetry. IEEE Geosci Remote Sensing Lett. 8:133-137.

Lauknes TR, Piyush Shanker A, Dehls JF, Zebker HA, Henderson IHC, Larsen Y. 2010. Detailed rockslide mapping in northern Norway with small baseline and persistent scatterer interferometric SAR time series methods. Remote Sensing Environ. 114:2097-2109.

Lee JS, Wen JH, Ainsworth TL, Chen KS, Chen AJ. 2009. Improved sigma filter for speckle filtering of SAR imagery. IEEE Trans Geosci Remote Sensing. 47:202-213.

Liao MS, Tang J, Wang T, Balz T, Zhang L. 2012. Landslide monitoring with high-resolution SAR data in the three gorges region. Sci China Earth Sci. 55:590-601.

Lu Y, Lei Z, Li H, Ni W, Yan W, Bian H. 2010. A modification to Goldstein algorithm for TerraSAR-X interferometic phase filter. Paper presented at: the 2nd International Conference on Computer and Automation Engineering (ICCAE); Singapore.

Mahmoud A, Elbialy S, Pradhan B, Buchroithner MF. 2011. Field-based landcover classification using TerraSAR-X texture analysis. Adv Space Res. 48:799-805. doi.org/10.1016/ j.asr.2011.04.005.

Malone AW, Hansen A, Hencher SR, Fletcher CJN. 2008. Post-failure movements of a large slow rock slide in schist near Pos Selim, Malaysia. In: Proceedings of the 10th International Symposium on Landslides and Engineered Slopes; Xi'an, China.

Manzo M, Berardino P, Bonano M, Casu F, Manunta M, Pepe A, Pepe S, Sansosti E, Solaro G, Tizzani P, et al. 2012. A quantitative assessment of DInSAR time series accuracy in volcanic areas: from the first to second generation SAR sensors. Paper presented at: the Geoscience and Remote Sensing Symposium (IGARSS), 2012 IEEE International; Munich.

Marghany M. 2012. DEM reconstruction of coastal geomorphology from DINSAR. In: Murgante B, Gervasi O, Misra S, Nadia N, Rocha AC, Taniar D, Apduhan BO, editors. Computational science and its applications - ICCSA 2012. Berlin Heidelberg: Springer; p. 435-446.

Massonnet D, Rossi M, Carmona C, Adragna F, Peltzer G, Feigl K, Rabaute T. 1993. The displacement field of the landers earthquake mapped by radar interferometry. Nature. 364:138-142.

Meisina C, Zucca F, Notti D, Colombo A, Cucchi A, Savio G, Giannico C, Bianchi M. 2008. Geological interpretation of Psinsar data at regional scale. Sensors. 8:7469-7492. 
Navarro-Sanchez VD, Lopez-Sanchez JM, Vicente-Guijalba F. 2010. A contribution of polarimetry to satellite differential SAR interferometry: increasing the number of pixel candidates. IEEE Geosci Remote Sensing Lett. 7:276-280.

Ojha C, Manunta M, Pepe A, Paglia L, Lanari R. 2012. An innovative region growing algorithm based on minimum cost flow approach for phase unwrapping of full-resolution differential interferograms. In: Geoscience and Remote Sensing Symposium (IGARSS), 2012 IEEE International; IEEE.

Papoutsis I, Papanikolaou X, Floyd M, Ji KH, Kontoes C, Paradissis D, Zacharis V. 2013. Mapping inflation at Santorini Volcano, Greece, using GPS and InSAR. Geophysic Res Lett. 40:267-272.

Pepe A, Berardino P, Bonano M, Euillades LD, Lanari R, Sansosti E. 2011. SBAS-based satellite orbit correction for the generation of DInSAR time-series: application to Radarsat-1 data. IEEE Trans Geosci Remote Sensing. 49:5150-5165.

Pepe A, Lanari R. 2006. On the extension of the minimum cost flow algorithm for phase unwrapping of multitemporal differential SAR interferograms. IEEE Trans Geosci Remote Sensing. 44:2374-2383.

Pepe A, Sansosti E, Berardino P, Lanari R. 2005. On the generation of ERS/ENVISAT DInSAR time-series via the SBAS technique. IEEE Geosci Remote Sensing Lett. 2:265269.

Pourghasemi H, Pradhan B, Gokceoglu C, Moezzi KD. 2013. A comparative assessment of prediction capabilities of Dempster-Shafer and weights-of-evidence models in landslide susceptibility mapping using GIS. Geomatics Nat Hazard Risk. 4:93-118.

Pradhan B, Hagemann U, Tehrany M, Prechtel N. 2013. An easy to use ArcMap based texture analysis program for extraction of flooded areas from TerraSAR-X satellite image. Comput Geosci. (Article online first available). doi.org/10.1016/j.cageo.2013.10.011.

Pradhan B, Lee S. 2010. Regional landslide susceptibility analysis using back-propagation neural network model at Cameron Highland, Malaysia. Landslides. 7:13-30.

Pradhan B, Lee S, Buchroithner MF. 2010a. Remote sensing and GIS-based landslide susceptibility analysis and its cross-validation in three test areas using a frequency ratio model. Photogrammetrie-Fernerkundung-Geoinformation. 2010:17-32.

Pradhan B, Lee S, Mansor S, Buchroithner M, Jamaluddin N, Khujaimah Z. 2008. Utilization of optical remote sensing data and geographic information system tools for regional landslide hazard analysis by using binomial logistic regression model. J Appl Remote Sensing. 2:1-11. doi:10.1117/1.3026536.

Pradhan B, Sezer EA, Gokceoglu C, Buchroithner MF. 2010b. Landslide susceptibility mapping by neuro-fuzzy approach in a landslide-prone area (Cameron Highlands, Malaysia). IEEE Trans Geosci Remote Sensing. 48:4164-4177.

Pradhan B, Shafie M, Pirasteh S. 2009. Maximum flood prone area mapping using RADARSAT images and GIS: Kelantan river basin. Int J Geoi. 5:11-23.

Rauste Y, Lateh HB, Wan Mohd MWI, Lonnqvist A, Hame T. 2012. TerraSAR-X data in cut slope soil stability monitoring in Malaysia. IEEE Trans Geosci Remote Sensing. 50:3354-3363.

Ren S, Chang W. 2012. Influence of geometric distortion on SAR image matching and its correction. J Remote Sensing. 16:467-481.

Roering JJ, Stimely LL, Mackey BH, Schmidt DA. 2009. Using DInSAR, airborne LiDAR, and archival air photos to quantify landsliding and sediment transport. Geophys Res Lett. 36:L19402. doi:10.1029/2009GL040374.

Sarychikhina O, Glowacka E, Suarez-Vidal F, Mellors R. 2010. DInSAR analysis of land subsidence caused by geothermal fluid exploitation in the Mexicali Valley, BC, Mexico. IAHS-AISH Publ. 339:268-273.

Schmitt M, Stilla U. 2010. A concept for reconstruction of urban surface models from airborne multi-aspect InSAR data. Paper presented at: the 8th European Conference on Synthetic Aperture Radar (EUSAR); Aachen, Germany. 
Shimada M. 1998. User's guide to NASDA's SAR products. 2nd ed. Tokyo: Earth Observation Research Centre (EORC)-National Space Development Agency (NASDA).

Shirzaei M, Bürgmann R, Foster J, Walter TR, Brooks BA. 2013. Aseismic deformation across the Hilina fault system, Hawaii, revealed by wavelet analysis of InSAR and GPS time series. Earth Planetary Sci Lett. 376:12-19. doi:10.1016/j.eps1.2013.06.011.

Sousa JJ, Hooper AJ, Hanssen RF, Bastos LC, Ruiz AM. 2011. Persistent scatterer InSAR: a comparison of methodologies based on a model of temporal deformation vs. spatial correlation selection criteria. Remote Sensing Environ. 115:2652-2663.

Strozzi T, Farina P, Corsini A, Ambrosi C, Thüring M, Zilger J, Wiesmann A, Wegmüller U, Werner C. 2005. Survey and monitoring of landslide displacements by means of L-band satellite SAR interferometry. Landslides. 2:193-201.

Sumantyo JTS, Shimada M, Mathieu P, Abidin HZ. 2012. Long-term consecutive DInSAR for volume change estimation of land deformation. IEEE Trans Geosci Remote Sensing. 50:259-270.

Sun G, Ranson KJ, Guo Z, Zhang Z, Montesano P, Kimes D. 2011. Forest biomass mapping from LiDAR and Radar synergies. Remote Sensing Environ. 115:2906-2916.

Trasatti E, Casu F, Giunchi C, Pepe S, Solaro G, Tagliaventi S, Berardino P, Manzo M, Pepe A, Ricciardi GP. 2008. The 2004-2006 uplift episode at Campi Flegrei Caldera (Italy): constraints from SBAS-DInSAR Envisat data and Bayesian source inference. Geophys Res Lett. 35:L07308.

Wang Q, Huang H, Yu A, Dong Z. 2011. An efficient and adaptive approach for noise filtering of SAR interferometric phase images. Geosci Remote Sensing Lett. 8:1140-1144.

Xianming X, Yiming P. 2011. Multi-baseline phase unwrapping algorithm based on the unscented Kalman filter. Radar Son Nav. 5:296-304.

Yin Y, Zheng W, Liu Y, Zhang J, Li X. 2010. Integration of GPS with InSAR to monitoring of the Jiaju landslide in Sichuan, China. Landslides. 7:359-365.

$\mathrm{Yu} \mathrm{JH}, \mathrm{Ge}$ L. 2010. Automatic exclusion of surface deformation in InSAR Dem generation using differential radar interferometry. Paper presented at: the Geoscience and Remote Sensing Symposium (IGARSS), 2010 IEEE International; Honolulu, HI. 